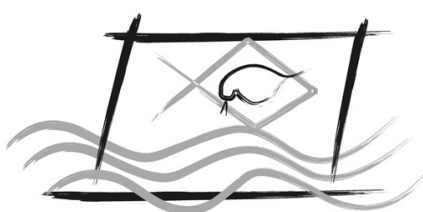

ECOTOX - BRASIL

\title{
Study ecotoxicity of biodiesel from residual oils and fats and the effects of salinity aquatic ecosystems
}

\author{
Camargo, R.P.L.; Carrim, A.J.I. \& Antoniosi Filho, N.R. \\ Laboratório de Métodos de Extração e Separação (LAMES), Instituto de Química, Universidade Federal de Goiás, Campus Samambaia, \\ CEP: 74690-900, Goiânia-GO, Brasil.
}

(Received February 17, 2017; Accept June 09, 2017)

\begin{abstract}
The increasing use of biodiesel raised concerns about its toxicological effects on the environment. However, few studies have analyzed the impact of biodiesel, especially ethyl biodiesel from residual frying oils and fats (RFOF), on aquatic organisms. Here, were used biodiesel produced by acid esterification followed the alkali transesterification and biodiesel produced by saponification, acidification and two acids esterification, both in the laboratory and their mixtures (B100, B20, and B7). The eluates were obtained by mixing biodiesel with saline water and tested the effect of several concentrations of them on the mortality rate of nauplii of the brine shrimp Artemia salina. The results of study showed that blend of diesel with greater proportion of biodiesel caused less mortality rate to A. salina nauplii. The saline eluate with $93 \%$ diesel and $7 \%$ biodiesel (E4 and E10) showed the mortality of $A$. salina on $50 \%$ eluate exposure while $\mathrm{E} 7$ it was $90 \%$. The mixture does increase toxicity with the presence of diesel, $\mathrm{B} 100$, only in $\mathrm{E} 8$ mortality occurred $\left(\mathrm{LD}_{50}=100 \%\right)$. Conversely, the eluates $\mathrm{E}_{\mathrm{R} 1 / 100}$ and $\mathrm{E}_{\mathrm{R} 2 / 100}$ produced from ethyl biodiesel of RFOF R1 and R2 biodiesel, respectively, did not have toxicity.
\end{abstract}

Keywords: Artemia salina, Ecotoxicology, Ethyl biodiesel.

\section{INTRODUCTION}

Biodiesel is a biofuel produced from a mixture of methyl or ethyl esters of fatty acids obtained from renewable sources, such as oils and fats. Its main characteristics are biodegradability, lack of sulfur and aromatic compounds, and excellent lubricity (D'agosto et al., 2015; Salvi \& Panwar, 2012). Several raw materials have been used for producing biodiesel, including residual frying oils and fats (RFOF). However, this material has quality problems, especially its low oxidative stability due to fatty acid oxidation during frying.

The increasing production of biodiesel raises concerns about its environmental impacts (Lapinskienè et al., 2006). Thus, biodiesel toxicity needs to be evaluated in order to understand and mitigate its environmental impacts. Toxicity tests and chemical analyzes are complementary, since the latter quantify toxic substances, while the former assess their effects on biological systems (Krull \& Barros, 2012)like Brazil, it is still a developing issue. The present study aimed to evaluate the use of Aquatic Ecotoxicology in Brazil based on the following key issues: the criteria for test organism selection; the most used species, routes, types of exposures and endpoints, and; the importance given to multispecies and in situ tests. A total of 227 publications authored by Brazilian researchers were analyzed and it was observed that among the reasons for test organism selection, its origin (native species. Simply quantifying such substances provide little information about their impact on the biota, since their toxicity may depend on interaction with other components of the effluent. Thus, it is often difficult to isolate a single toxic substance (Jalava et al., 2012; Williams et al., 2015).

Most toxicological studies involving biodiesel have evaluated its impact on air pollution, especially those produced from canola using the methyl route, since this is the most commonly used biodiesel in Europe and the United States (Ajanovic, 2011; Firrisa et al., 2014). Conversely, the effects of ethyl biodiesel received less attention. For example, Swanson et al. (2009) compared the effects of organic extracts of particulate matter emitted by the combustion of ethyl and 
methyl soybean biodiesel and diesel on human respiratory epithelial cells. However, it is still difficult to extrapolate these experimental results to human populations (Cavalcante et al., 2014; Lapinskienè et al., 2006).

However, few ecotoxicology studies have investigated the effects of biodiesel on aquatic environments. For example, Chae et al. (2005) found that the biodiesel obtained via the methyl route is slightly toxic to the freshwater microalga Chlorella vulgaris. Other studies e.g., Da Cruz et al. (2012); Khan et al. (2007); Leite et al. (2011); Nogueira et al. (2011); Yassine et al. (2012)produces less harmful combustion emissions, and biodegrades more easily. Like diesel spills, biodiesel can have deleterious effects on the aquatic environments. The effect of neat biodiesel, biodiesel blends, and diesel on Oncorhynchus mykiss and Daphnia magna was evaluated using acute toxicity testing. Static nonrenewal bioassays of freshwater organisms containing B100, B50, B20, B5, and conventional diesel fuel were used to compare the acute effects of biodiesel to diesel. Mortality was the significant end point measured in this study; percent mortality and lethal concentration (LC50; Nogueira et al. (2013) Tjarinto et al. (2014) also tested the toxicity of methyl biodiesel. They found that diesel/biodiesel blends can contaminate freshwater environments, due to toxic and recalcitrant substances, including volatile organic compounds, aromatic components, and their derivatives (Mitre et al., 2012).

However, few studies tested the toxicity of ethylic biodiesel to aquatic organisms. For example, Bedin (2013) compared the toxicity of commercial ethyl alcohol derived from different oilseeds against their mixtures with diesel (B5, B20, and B100) to the Nile Tilapia (Oreochromis niloticus). He found that the B5 and B20 blends are more toxic than the B100. Also, the pure diesel is more toxic than all other samples, probably due to the PAH composition.

Nonetheless, no study evaluated the toxicity of ethylic biodiesel to salt or brackish water organisms. In order to reduce its toxicity, the methyl biodiesel should contain as little as possible methanol, but it is need to knows if the same occur as residual ethanol from the production of ethyl biodiesel (Da Cruz et al., 2012; Gateau et al., 2005; Leite et al., 2011; Rosen et al., 2014)while reducing greenhouse gas emissions. However, the toxicity of products and effluents from the biodiesel industry has not yet been sufficiently investigated. Brazil has a very high potential as a biodiesel producer, in view of its climatic conditions and vast areas for cropland, with consequent environmental risks because of possible accidental biodiesel spillages into water bodies and runoff to coastal areas. This research determined the toxicity to two marine organisms of the water-soluble fractions (WSF.

One of the most used organisms in ecotoxicological assessments is the brine shrimp, Artemia salina (Crustacea: Anostraca). This species inhabits aquatic saline environments and can be easily cultured under laboratory conditions. Despite being the largest of Earth's aquatic environments, saline environments are neglected by most ecotoxicological studies (Sorgeloos et al., 1978).
Artemia salina is a non-selective filter feeder that occurs in environments with a wide range of salinity ( 5 to 250 g.L.- ${ }^{-1}$ ) and temperature $\left(6\right.$ to $\left.35^{\circ} \mathrm{C}\right)$. It has a short life cycle, highly adaptable to adverse environments, and parthenogenetic reproduction (with nauplii or small cysts) (Matthews, 1995; Nunes et al., 2006; Sorgeloos et al., 1978). A commonly estimated parameter is the lethal dose $\left(\mathrm{LD}_{50}\right)$ of a given substance necessary to kills $50 \%$ of the individuals exposed (Krull \& Barros, 2012; like Brazil, it is still a developing issue. The present study aimed to evaluate the use of Aquatic Ecotoxicology in Brazil based on the following key issues: the criteria for test organism selection; the most used species, routes, types of exposures and endpoints, and; the importance given to multispecies and in situ tests. A total of 227 publications authored by Brazilian researchers were analyzed and it was observed that among the reasons for test organism selection, its origin (native speciesWilliams et al., 2000)like Brazil, it is still a developing issue. The present study aimed to evaluate the use of Aquatic Ecotoxicology in Brazil based on the following key issues: the criteria for test organism selection; the most used species, routes, types of exposures and endpoints, and; the importance given to multispecies and in situ tests. A total of 227 publications authored by Brazilian researchers were analyzed and it was observed that among the reasons for test organism selection, its origin (native species. Here, were tested the toxicity of the soluble fraction (eluate) of the ethyl biodiesel from RFOF on the mortality rate of nauplii of A. salina. Specifically, were used two biodiesel: production obtained via esterification followed by transesterification of the RFOF and another obtained via saponification, acidification, and double esterification.

\section{MATERIAL AND METHODS}

\section{Production of ethyl biodiesel from residual fry oils and fats by acid esterification followed the alkali transesterification (R1)}

The production was started with $2.5 \%$ sulfuric acid to form the esterifying reagent, which then was mixed to raw material at 11:1 (w/w) reagent molar ratio. This mixture was placed in a reactor at $70{ }^{\circ} \mathrm{C}$ for $4 \mathrm{~h}$ under stirring at $450 \mathrm{rpm}$. Then, removed of ethanol in rotary evaporator (Quimis ${ }^{\circledR}-$ Q344B2), the reduced pressure (Prismatec pump model I22-BCP). The grease material was washed with warm water until the water $\mathrm{pH}$ 6.0. The grease material rested to separate the water. Then, a distillation the reduced pressure and filtration with sodium sulfate were carried out.

Later, alkali transesterification was done the in reactor (Marconi, MA 159/150) with automatic agitator (IKA® RW 20). Then, $1.5 \%$ potassium hydroxide was solubilized in ethanol to form the potassium ethoxide catalyst, which then was mixed to grease material at 13:1 (w/w) ratio reagent molar. This mixture was placed in a reactor at $70{ }^{\circ} \mathrm{C}$ for $4 \mathrm{~h}$ under stirring at $800 \mathrm{rpm}$. The ethanol was removed by rotary evaporator with reduced pressure. The mixture of biodiesel 
and glycerol was allowed to stand at 24 hours. The glycerol was separated. The biodiesel was washed with solution hydrochloric acid $1.0 \mathrm{~mol} \mathrm{~L}^{-1}$ and water distillation. Then, a distillation the reduced pressure and filtration with sodium sulfate were carried out.

\section{Production of ethyl biodiesel from residual fry oils and fats by saponification, acidification and two acids esterification (R2)}

The production was started with saponification from residual oils and fats. The solution $30 \%(\mathrm{v} / \mathrm{v})$ potassium hydroxide was mixed to raw material in a reactor at $90{ }^{\circ} \mathrm{C}$ for $2 \mathrm{~h}$ under stirring at $200 \mathrm{rpm}$. After the saponification, the product was allowed to stand at 12 hours to separate of glycerol. Then, the acidification for production of free fats acid was realized, by method developed Suarez et al. (2015).

For acidification, phosphoric acid (more than 50\% volume of saponification product) was added to reactor with automatic agitator until the solution was acidic ( $\mathrm{pH}$ ?). The mixture of biodiesel and glycerol was allowed to stand at 8 hours. The free fats acid and water were separated from the residual potassium by filtration. Then, the water was separated from free fats acid by decantation and filtration with sodium sulfate. For impurities reduction, the free fats acid was mixture with hexane at 1:1 (w/w) ratio reagent molar. After, the solvent was removed by rotary evaporator under reduced pressure. The free fats acid was washed with warm water until the $\mathrm{pH}$ 7.0. The product was filtration with sodium sulfate was carried out. After this process two acids esterification were carried out in series, according to the method cited above.

\section{Ecotoxicological essay}

The essay was realized of according method by Meyer et al. (1982) in biodiesel produced using acid esterification followed by alkaline transesterification (sample R1), other biodiesel using saponification followed by acidification and two acid esterifications (sample R2), and biodiesel/diesel mixtures. Ecotoxicological tests followed the standards L5.019 (CETESB, 1990) and L5.021 (CETESB, 1991), which contain instructions for the cultivation of $A$. salina nauplii and for conducting ecotoxicological tests using A. salina, respectively.

\section{Preparation of the eluate}

Eluate is the water soluble fraction of biodiesel and BX mixtures, as defined by ABNT 15469: 2007: "the aqueous solution of a sample of low miscibility in water obtained after extraction with water" (ABNT, 2007). Each eluate was prepared by adapting the standard ABNT NBR 15469:2007. Specifically, each biodiesel and its respective BX mixtures were mixed with $3.5 \%(\mathrm{w} / \mathrm{v})$ aqueous saline solution, in a ratio of $750 \mathrm{~mL}$ of sample with $250 \mathrm{~mL}$ of aqueous saline solution. These mixtures remained stirring at $150 \mathrm{rpm}$ for $24 \mathrm{~h}$ in a reactor (Marconi MA 502). After $24 \mathrm{~h}$, the mixture was transferred to a funnel, where it remained for $24 \mathrm{~h}$ to for a complete separation of the eluate from the oil. The eluate (Table 1) was stored in plastic HDPE bottles under refrigeration.

Table 1. Characteristics of eluate samples.

\begin{tabular}{lc}
\hline Sample used to produce eluates & Eluate code \\
\hline RFOF & $\mathrm{E}_{1}$ \\
Biodiesel R1 & $\mathrm{E}_{2}$ \\
Mixture B20 of Biodiesel R1 & $\mathrm{E}_{3}$ \\
Mixture B7 of Biodiesel R1 & $\mathrm{E}_{4}$ \\
Biodiesel R2 & $\mathrm{E}_{5}$ \\
Mixture B20 of Biodiesel R2 & $\mathrm{E}_{6}$ \\
Mixture B7 of Biodiesel R2 & $\mathrm{E}_{7}$ \\
\hline Mixtures B7 and B20 are blends of 7\% and 20\% of biodiesel in diesel.
\end{tabular}

\section{Cultivation of Artemia salina nauplii}

Artemia salina eggs were cultured following Meyer et al. (1982) in a $1 \mathrm{~mL}$ separatory funnel filled with a $3.5 \%(\mathrm{w} / \mathrm{v})$ aqueous saline solution. It was added $30 \mathrm{mg}$ of $A$. salina eggs to the funnel, which was placed in an incubator at $25^{\circ} \mathrm{C}$ (Marconi MA 403) with an aquarium pump whose flow was $4.5 \mathrm{~L} \cdot \mathrm{min}^{-1}$. Eggs were incubated for $48 \mathrm{~h}$, with a $23 \mathrm{~h}: 1 \mathrm{~h}$ dark:light regime and $10 \mathrm{~min}$ intervals during cultivation, under aeration. After $48 \mathrm{~h}$, eggs hatched and aeration was removed. Hatching eggs, which remained in the bottom, were separated from those that did not hatch, which remained in the upper part of the funnel. Nauplii were in the middle of the culture medium.

The volume 500 to $700 \mathrm{~mL}$ of culture medium with the nauplii was transferring them to a beaker with about $100 \mathrm{~mL}$ of the culture medium. Then, it washed the filter with distilled water to remove nauplii and transferred them to the beaker. It was put a light at the top of the beaker to keep the nauplii suspended in the solution.

\section{Ecotoxicological test of the eluate}

The nine solutions with different concentrations of eluates $(100 \%, 90 \%, 80 \%, 70 \%, 60 \%, 50 \%, 40 \%, 30 \%$, and $0 \%)$ were used to test its effects on the mortality rate of nauplii. In each test tube placed about 10 nauplii of A. salina. Test tubes were incubated for $24 \mathrm{~h}$ at $30{ }^{\circ} \mathrm{C}$ and at $141.3 \mu \mathrm{mol} . \mathrm{m}^{2} . \mathrm{s}$ illumination. Ten replicates for each eluate concentration, and counted the number of dead nauplii using a dissecting microscope, to determine the mortality rate and the eluate concentration that kills $50 \%$ of the specimens $\left(\mathrm{LD}_{50}\right)$. Alive nauplii were those that moved for at least $10 \mathrm{~s}$.

\section{RESULTS AND DISCUSSION}

The samples of biodiesel R1 and R2 meet all quality standards (Table 2) required by the Brazilian National Agency for Petroleum (Resolution 45/2014), except for oxidative stability, which is usually low for biodiesel from unsaturated oils (e.g., soybean) and especially those with oxidized components, such as frying oils. 
It was produced two diferent biodiesel with the purpose to evaluate if the production route could influence in a suitable ecotoxicological situation. Some biodiesel properties can be directly linked on microbiological growth during its storage, such as acidity, the oxidative stability, water contente and contaminants such as glycerol and mono-di-tri-glycerides.

Table 2. Quality characteristics of the R1 and R2 biodiesel samples used for the preparation of eluates.

\begin{tabular}{|c|c|c|c|c|}
\hline \multirow{2}{*}{ Parameter } & \multirow{2}{*}{ Limits } & \multirow{2}{*}{ Unit } & \multicolumn{2}{|c|}{ Results } \\
\hline & & & $\mathrm{R} 1$ & $\mathrm{R} 2$ \\
\hline Acidity number & 0.5 & $\mathrm{mg} \mathrm{KOH} \mathrm{g}^{-1}$ & 0.39 & 0.44 \\
\hline Iodine value & - & g. $100 \mathrm{~g}^{-1}$ & 122.47 & 119.32 \\
\hline Oxidative Stability & 8 & $\mathrm{~h}$ & 5.82 & 5.02 \\
\hline $\begin{array}{l}\text { Kinematic viscosity } \\
\left(40^{\circ} \mathrm{C}\right)\end{array}$ & 30 a 6.0 & $\mathrm{~mm}^{2} \cdot \mathrm{s}^{-1}$ & 4.85 & 5.11 \\
\hline Water content & 200 & mg. $\mathrm{kg}^{-1}$ & 171.00 & 142.80 \\
\hline Ester Content & 96.5 & $\%$ mass & 96.83 & 97.10 \\
\hline $\mathrm{Na}+\mathrm{K}$ & $5 \max$ & mg.kg-1 & 2.20 & 0.39 \\
\hline $\mathrm{Ca}+\mathrm{Mg}$ & $5 \max$ & mg.kg-1 & 0.16 & 0.89 \\
\hline $\mathrm{P}$ & $10 \max$ & mg.kg-1 & 0.00 & 0.28 \\
\hline Sulphur content & $10 \max$ & mg. $\mathrm{kg}^{-1}$ & 4.80 & 6.50 \\
\hline Free glycerol & $0.02 \max$ & $\%$ mass & 0.02 & 0.01 \\
\hline Total Glycerol & $0.25 \max$ & $\%$ mass & 0.20 & 0.09 \\
\hline Monoacylglycerol & $0.70 \max$ & $\%$ mass & 0.62 & 0.29 \\
\hline Diacylglycerol & $0.20 \max$ & $\%$ mass & 0.10 & 0.08 \\
\hline Triacylglycerol & $0.20 \max$ & $\%$ mass & 0.05 & 0.09 \\
\hline
\end{tabular}

The prepatation of eluate the consist of a bioassay focused

on ethylic biodiesel studies as well as its mixtures with diesel oil. The eluates were prepared with saline solution from ecotoxicological assays in proportions of 0 to $100 \%$ eluate in solution. The results found for mortality or immobilization of Artemia saline at each concentration and in each eluate are shown in Table 3. From the data in Table 3 , the $\mathrm{LD}_{50}$ values for each eluate were calculated.

The lowest mortality rate of $A$. salina was recorded in eluates E2, E5, and E3 (Table 3). Since all specimens survived in these eluates, the $\mathrm{LD}_{50}$ could not be calculated. The sample B100 was even less harmful to A. salina than the RFOF itself, since the eluate of RFOF had an $\mathrm{LD}_{50}$ of $98 \%$ (Table 3). Thus, the B100 (pure biodiesel) and its mixtures with diesel in seawater would be less harmful to the biota in case of spilling, given that solubilizing agents (e.g., surfactants) are absent.

The toxicity of both R1 and R2 increased with increasing concentration of diesel in the BX mixture. The toxicity of diesel is usually due to highly toxic PAHs (polycyclic aromatic hydrocarbons), which are volatile organic compounds with high sulfur content (Karavalakis et al., 2010; Rosen et al., 2014). In relation of routes of biodiesel production used in
Table 3. Mortality rate and immobilization of Artemia salina in ecotoxicological assays at different concentrations of eluates.

\begin{tabular}{lccccccc}
\hline $\begin{array}{l}\text { Eluate } \\
\text { concentration }\end{array}$ & \multicolumn{6}{c}{ Mean mortality rate of Artemia salina } \\
\cline { 2 - 8 } $\begin{array}{l}\text { in saline } \\
\text { water }\end{array}$ & $\mathrm{E}_{1}$ & $\mathrm{E}_{2}$ & $\mathrm{E}_{5}$ & $\mathrm{E}_{3}$ & $\mathrm{E}_{6}$ & $\mathrm{E}_{4}$ & $\mathrm{E}_{7}$ \\
\hline $100 \%$ & $63 \%$ & $8 \%$ & $35 \%$ & $13 \%$ & $77 \%$ & $96 \%$ & $96 \%$ \\
$90 \%$ & $5 \%$ & $3 \%$ & $5 \%$ & $2 \%$ & $34 \%$ & $82 \%$ & $72 \%$ \\
$80 \%$ & 0 & 0 & 0 & 0 & $3 \%$ & $78 \%$ & $21 \%$ \\
$70 \%$ & 0 & 0 & 0 & 0 & 0 & $75 \%$ & $5 \%$ \\
$60 \%$ & 0 & 0 & 0 & 0 & 0 & $68 \%$ & 0 \\
$50 \%$ & 0 & 0 & 0 & 0 & 0 & $55 \%$ & 0 \\
$40 \%$ & 0 & 0 & 0 & 0 & 0 & $10 \%$ & 0 \\
$30 \%$ & 0 & 0 & 0 & 0 & 0 & 0 & 0 \\
$0 \%$ & 0 & 0 & 0 & 0 & 0 & 0 & 0 \\
\hline $\mathrm{LD}_{50}$ & $98 \%$ & - & - & - & $94,0 \%$ & $48,5 \%$ & $86,0 \%$ \\
\hline
\end{tabular}

this paper, it could be noticed that the route involving acid esterification followed the acid esterification followed the alkali transesterification (R1) is more suitable to dicrease ecotoxicological effects, leading to a lower toxicity, compared to route $\mathrm{R} 2$.

The samples B7, whose biodiesel concentration was identical to those commonly found in Brazil, caused mortality of A. salina nauplii in concentrations of $40 \%$. The mortality rate is substantial only in concentrations equal to or greater than $90 \%$ in samples with $20 \%$ of biodiesel. Thus, diesel with higher proportion of biodiesel could be less harmful to seawater organisms in the case of a spill.

\section{CONCLUSION}

When comparing ethylic biodiesel of residual fry oils and fats with their raw material, it could be noticed that the conversion to biodiesel dicreases the impact effects of these residual oils on aquatic environment. Thus, it was noticed that biodiesel concentration in diesel increases and inhibits further the biodiesel toxicity on saline medium, which could be beneficial to aquatic biota at the tropic level evaluated, in case of such same samples being spilled on saline or brackish water. Also, two routes of production tested, R1 and R2, it could be noticed a considerably lower toxicological effect when using route $\mathrm{R} 1$ by acid esterification followed by alkali transesterification. Therefore, ecotoxicological assays using A. salina provided useful information about the environmental impacts of an oil spill in the ocean.

\section{ACKNOWLEDGEMENTS}

To MCT, FINEP, FUNAPE and CNPq for their financial support. The CNPq Rúbia de Pina Luchetti Camargo's scholarship and Nelson Roberto Antoniosi Filho's productivity fellowship. 


\section{REFERENCES}

ABNT NBR 15469. 2007. Ecotoxicologia aquática - Preservação e preparo de amostras. Rio de Janeiro: ABNT.

AJANOVIC, A. 2011. Biofuels versus food production: does biofuels production in-crease food prices? Energy, 36 (4): 2070-2076. http://dx.doi.org/10.1016/j.energy.2010.05.019.

BEDIN, B.H. 2013. Avaliação de biomarcadores bioquímicos em tilápias (Oreo-chromis niloticus) expostos a óleo diesel e biodiesel. São José do Rio Preto.

CAVALCANTE, D.G.S.M., DA SILVA, N.D.G., MARCARINI, J.C., MANTOVANI, M.S., MARIN-MORALES, M.A., MARTINEZ, C.B.R. 2014. Cytotoxic, biochemical and genotoxic effects of biodiesel produced by different routes on ZFL cell line. Toxicol. Vitro, 28 (6): 1117-1125. http://dx.doi. org/10.1016/j.tiv.2014.05.008.

CETESB. 1990. Norma técnica L5019: Procedimentos para utilização de testes de toxicidade no controle de efluentes líquidos. São Paulo, SP.

CETESB. 1991. Norma Técnica L5021: Água do mar - Teste de toxicidade aguda com Artemia: método de ensaio. São Paulo, SP.

CHAE, H. J.; YONG, K. E.; HEON, L. J. 2005. Toxicity test of biodiesel and biodiesel-derived neopentyl polyol ester lubricant oil base using microalgae. Korean Soc. Biotechnol. Bioeng. J., 20 (1): 55-59.

DA CRUZ, A.C., LEITE, M.B., RODRIGUES, L.E., NASCIMENTO, I.A. 2012. Estimation of biodiesel cytotoxicity by using acid phosphatase as a biomarker of lysosomal integrity. Bull. Environ. Contam. Toxicol., 89 (2): 219-224. http://dx.doi. org/10.1007/s00128-012-0707-7.

D'AGOSTO, M.A., DA SILVA, M.A.V., DE OLIVIERA, C.M., FRANCA, L.S., MARQUES, L.G.C., MURTA, A.L.S., DE FREITAS, M.A.V. 2015. Evaluating the potential of the use of biodiesel for power generation in Brazil. Renew Sust. Energ. Rev., 43 (1): 807-817. http://dx.doi.org/10.1016/j.rser.2014.11.055.

FIRRISA, M.T., VAN DUREN, I., VOINOV, A. 2014. Energy efficient for rapeseed biodiesel production in different farming systems. Energy Efficiengy, 7 (1): 79-95. http://dx.doi. org/10.1007/s12053-013-9201-2.

GATEAU,P., VANDIEVOET,F.,BOUILLON,V., VERMEERSCH, G., CLAUDE, G., STAAT, F. 2005. Environmentally friendly properties of vegetable oil methyl esters. Ol Corps Gras Lipides, 12 (4): 308-313. http://dx.doi.org/10.1051/ocl.2005.0308.

JALAVA, P.I., HAPPO, M.S., KELZ, J., BRUNNER, T., HAKULINEN, P., MAKI-PAAKKANEN, J., HUKKANEN, A., JOKINIEMI, J., OBERNBERGER, I., HIRVONEN, M. 2012. Invitro toxicological characterization of particulate emissions from residential biomass heating systems based on old and new technologies. Atmosph. Environ., 50 (1): 24-35. http://dx.doi. org/10.1016/j.atmosenv.2012.01.009.

KARAVALAKIS, G., DEVES, G., FONTARAS, G., STAMOULIS, S., SAMARAS, Z., BAKEAS, E. 2010. The impact of soy-based biodiesel on $\mathrm{PAH}$, nitro-PAH and oxy-PAH emissions from a passenger car operated over regulated and nonregulated driving cycles. Fuel, 89 (12): 3876-3883. http://dx.doi.org/10.1016/j. fuel.2010.07.002

KHAN, N.; WARITH, M. A; LUK, G. A comparison of acute toxicity of biodiesel, biodiesel blends, and diesel on aquatic organisms. 2007. J. Air Waste Manag. Assoc., 57 (3): 286-296. http://dx.doi.org/10.1080/10473289.2007.10465333

KRULL, M., BARROS, F. 2012. Key Issues in Aquatic Ecotoxicology in Brazil: A Critical Review. J. Braz. Soc. Ecotoxicol., 7027 (2): 57-66. http://dx.doi.org/10.5132/jbse.2012.02.009.

LAPINSKIENĖ, A., MARTINKUS, P., RĖBŽDAITĖ, V. 2006. Eco-toxicological studies of diesel and biodiesel fuels in aerated soil. Environ. Poll. 142 (3): 432-437. http://dx.doi.org/10.1016/j. envpol.2005.10.023.
LEITE, M.B., DE ARAUJO, M.M., NASCIMENTO, I.A., DA CRUZ, A.C., PEREIRA, S.A., DO NASCIMENTO, N.C. 2011. Toxicity of water-soluble fractions of biodiesel fuels derived from castor oil, palm oil, and waste cooking oil. Environ. Toxicol. Chem., 30 (4): 893-897. http://dx.doi.org/10.1002/etc.444.

MATTHEWS, R. S. 1994. Artemia salina as a test organism for measuring superoxide-mediated toxicity. Free. Radic. Biol. Med., 18 (5): 919-922. http://dx.doi.org/10.1016/08915849(94)00205-X.

MEYER, B.N., FERRIGNI, N.R., PUTNAM, J.E., JACOBSEN, L.B., NICHOLS, D.E., McLAUQHLIN, J.L. 1982. Brine shrimp: A convenient general bioassay for active plant constituents. J. Med. Plant. Res., 45: 31-34. http://dx.doi.org/10.1590/S151605722012000200016.

MITRE, T.K., LEÃO, M.M.D., ALVARENGA, M.C.N. 2012. Tratamento de águas contaminadas por diesel/biodiesel utilizando processo Fenton. Eng. Sanit. Ambien., 17 (2):129-136. http:// dx.doi.org/10.1590/S1413-41522012000200001.

NOGUEIRA, L., SANCHES, A.L.M., DA SILVA, D.G., FERRIZI, V.C., MOREIRA, A.B., DE ALMEIDA, E.A. 2011. Biochemical biomarkers in Nile tilapia (Oreochromis niloticus) after shortterm exposure to diesel oil, pure biodiesel and biodiesel blends. Chemosphere. 85 (1): 97-105. http://dx.doi.org/10.1016/j. chemosphere.2011.05.037.

NOGUEIRA, L., DA SILVA, D.G., OLIVEIRA, T.Y., DA ROSA, J.M., FELICIO, A.A., DE ALMEIDA, E.A. 2013. Biochemical responses in armored catfish (Pterygoplichthys anisitsi) after short-term exposure to diesel oil, pure biodiesel and biodiesel blends. Chemosphere. 93 (2): 311-319. http://dx.doi. org/10.1016/j.chemosphere.2013.04.083.

NUNES, B.S., CARVALHO, F.D., GUILHERMINO, L.M., STAPPEN, G.V. 2006. Use of the genus Artemia in ecotoxicity testing. Environ. Poll. 144: 453-462. http://dx.doi.org/10.1016/j. envpol.2005.12.037.

ROSEN, G., DOLECAL, R.E., COLVIN, M.A., GEORGE, R.D. 2014. Preliminary ecotoxicity assessment of new generation alternative fuels in seawater. Chemosphere. 104: 265-270. http:// dx.doi.org/10.1016/j.chemosphere.2013.11.023.

SALVI, B. L.; PANWAR, N. L. Biodiesel resources and production technologies - A review. 2012. Renew. Sustain. Energy Rev. 16 (6): 3680-3689. http://dx.doi.org/10.1016/j.rser.2012.03.050.

SORGELOOS, P.; REMICHE-VAN, C.D.W.; PERSOONE, G. 1978. The use of Artemia nauplii for toxicity tests-A critical analysis. Ecotoxicol. Environ. Safet. 2 (3): 249-255. http:// dx.doi.org/10.1016/S0147-6513(78)80003-7.

SUAREZ, P.A.Z.; LIRA, H.N., RODRIGUEZ, C.G.V. 2015. Estudo dos parâmetros físico-químicos para a reação de hidroesterificação. Parâmetros Fisico-quimico para os processos de produção de Biodiesel, p. 81-154.

SWANSON, K.J., KADO, N.Y., FUNK, W.E., PLEIL, J.D., MADDEN, M.C., GHIO, A.J. 2009. Release of the proinflammatory markers by BEAS-2B cells following in vitro exposure to biodiesel extracts. Open Toxicol. J., 3: 8-15. http:// dx.doi.org/10.2174/ 1874340400903010008.

TJARINTO, R.; RACHMATIAH, I.; SALAMI, S. 2014. Toxicity Test of Water Soluble Fractions of Waste Vegetable Oil Based Biodiesel and Biodiesel / Diesel Blends on Daphnia magna and Allium cepa. Intern. Energy Conferen. p. 13-14.

WILLIAMS, P.L., JAMES, R.C., ROBERTS, S.M. 2015. Principles of toxicology : environmental and industrial applications. John Wiley \& Sons, New York. 496 p.

YASSINE, M.H., WU, S., SUIDAN, M.T., VENOSA, A.D. 2012. Microtox aquatic toxicity of petrodiesel and biodiesel blends: The role of biodiesel's autoxidation products. Environ. Toxicol. Chem., 31 (12): 2757-2762. http://dx.doi.org/10.1002/etc.2001. 